\title{
Podridão de Frutos de Jiló Causada por Phytophthora capsici
}

\author{
Aldir de O. de Carvalho', Dartanhã J. Soares ${ }^{2}$, Robert W. Barreto² \& Margarida Goréte F. do Carmo ${ }^{1}$ \\ ${ }^{1}$ Departamento de Fitotecnia, UFRRJ, CEP 23890-000, Seropédica, RJ; ${ }^{2}$ Departamento de Fitopatologia UFV, \\ CEP 36570-000, Viçosa, MG, e-mail: gorete @ufrrj.br
}

(Aceito para publicação em 22/10/2004)

Autor para correspondência: Aldir de Oliveira de Carvalho

\begin{abstract}
Fruit rot of Solanum gilo caused by Phytophthora capsici

A fruit rot of Solanum gilo, caused by Phytophthora capsici, is reported for the first time. The isolate obtained from S. gilo was also capable of inducing fruit rot on green pepper (Capsicum annuum), zucchini (Cucurbita moschata), cucumber (Cucumis sativus), and chayote (Sechium eduli).
\end{abstract}

No período de novembro de 2003 a fevereiro de 2004 , em mercados da zona oeste do Rio de Janeiro, observou-se a presença de frutos verdes de jiló (Solanum gilo Raddi), procedentes da região serrana do Estado, apresentando sintomas de escurecimento da casca e, em estádios mais avançados, apodrecimento da polpa e escurecimento total do fruto. Os frutos foram levados para o laboratório de Epidemiologia do Departamento de Fitotecnia da Universidade Federal do Rio de Janeiro (UFRRJ), onde foram mantidos em câmara úmida durante $24 \mathrm{~h}$, seguido de mais 24 h sem câmara úmida. Decorrido este período, observouse sobre as lesões, inicialmente marrom-pardas, abundante esporulação de aspecto eflorescente (Figura 1A e B). Observações feitas ao microscópio estereoscópico e óptico, possibilitaram classificar o patógeno como pertencente ao gênero Phytophthora. Fez-se isolamento em BDA. O fungo isolado foi inoculado, pela deposição de disco de micélio, em frutos de jiló, pimentão (Capsicum annuиm L.), abobrinha (Cucurbita moschata Duch.), pepino (Cucumis sativus L.), chuchu (Sechium eduli Tacq. Swartz) e cacau (Theobroma cacao L.) e no colo e folhas de mudas de jiló, previamente feridos com agulha esterilizada, e submetidos à câmara úmida. Em todas as inoculações, exceto em frutos de cacau, houve a reprodução dos sintomas. De acordo com as características culturais: colônias de aspecto cotonoso com crescimento radial tipo "teia de aranha"; morfológicas: esporângios pedicelados, caducos, ovóides (Figura 1C), formados em ramificações irregulares, com uma ou duas papilas, anterídio anfígeno, oósporo plerótico e biométricas: pedicelo 20,0-43,5 $\mu \mathrm{m}$, esporângio 21,5-31,0 x 46,5-59,5 $\mu \mathrm{m}$, anterídio 13,0-20,0 x 10,0-15,0 $\mu \mathrm{m}$, oósporo 23,0-34,0 $\mu \mathrm{m}$ de diâmetro e 1,0-3,0 $\mu \mathrm{m}$ de espessura (Figura 1D) a espécie foi classificada como Phytophthora capsici Leonian (Waterhouse, Mycological Papers, $n^{\circ} 122$, 1970). Esta é a primeira constatação deste patógeno em frutos de jiló (Erwin \& Ribeiro, Phytopthora Diseases Wordwide, 1996).

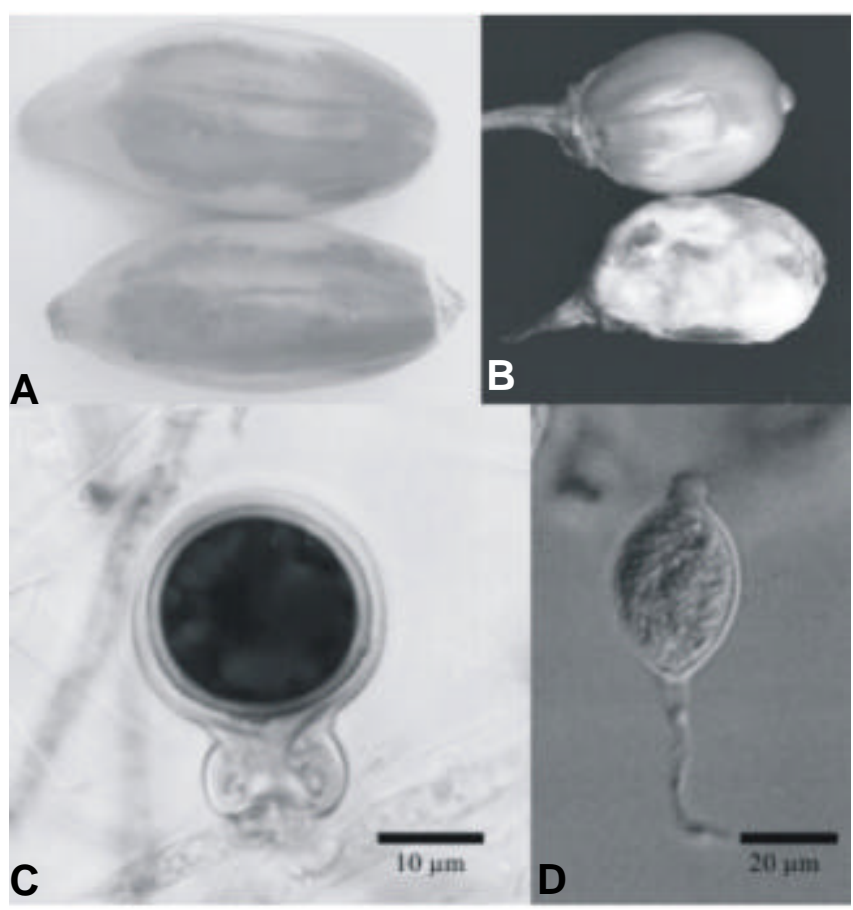

FIG. 1 - Phytophthora capsici em frutos de jiló (Solanum gilo). (A) Frutos coletados em mercado da zona oeste do Rio de Janeiro com lesões marrom-pardas, (B) resultado do teste de patogenicidade em frutos de jiló com esporulação de aspecto eflorescente, (C) oósporo e anterídio, (D) esporângio pedicelado. 